Zeszyty Naukowe Szkoły Głównej Gospodarstwa Wiejskiego w Warszawie Problemy Rolnictwa Światowego tom 17 (XXXII), zeszyt 3, 2017: 29-38

DOI: 10.22630/PRS.2017.17.3.50

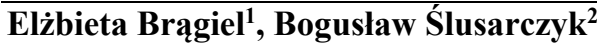

${ }^{1}$ Państwowa Wyższa Szkoła Zawodowa im. Stanisława Pigonia w Krośnie

${ }^{2}$ Uniwersytet Rzeszowski

\title{
Tendencje na europejskim rynku żywności ekologicznej
}

\section{Trends on the European Organic Food Market}

\begin{abstract}
Synopsis. Celem artykułu jest analiza wielkości sprzedaży i konsumpcji produktów ekologicznych oraz trendów występujących na tym rynku w poszczególnych krajach Europy a zwłaszcza UE. Podstawę analizy stanowiły dane IFOAM i FIBL z lat 2000-2015, a także zagraniczna i krajowa literatura przedmiotu. Sformułowano wnioski końcowe: większy wzrost wielkości sprzedaży produktów ekologicznych na przestrzeni omawianych piętnastu lat odnotowuje się w Europie niż w grupie krajów UE. Najwyższą sprzedaż produktów ekologicznych w 2014, 2015 roku osiagnęły Niemcy, Francja, Wielka Brytania, Włochy i Szwajcaria. Na przestrzeni lat 2005-2014 różnica w wydatkach na żywność ekologiczną na jednego mieszkańca UE w porównaniu do całej Europy powiększała się z każdym rokiem. Biorąc pod uwagę rosnący udział produktów ekologicznych w strukturze spożycia współczesnych społeczeństw należy prowadzić szeroko zakrojone badania na ten temat.
\end{abstract}

Slowa kluczowe: rolnictwo ekologiczne, produkcja ekologiczna, rynek produktów ekologicznych, zrównoważony rozwój, Unia Europejska, Europa

\begin{abstract}
The aim of the article is to analyze the size of sales, consumption of organic products and trends observed on the organic food market in individual European countries - especially in the EU. The basis for the analysis was IFOAM and FIBL data from the years 2000-2015, as well as foreign and domestic literature of the subject. The following final conclusions were drawn: a greater increase in the volume of sales of organic products over the determined fifteen years is observed in Europe than in the group of countries in the European Union. The highest sale of organic products in 2014 and 2015 was achieved by Germany, France, United Kingdom, Italy and Switzerland. Over the years 2005-2014, the difference in expenditure on organic food per capita in the EU in comparison to the whole of Europe has grown every single year. Taking into account the growing share of organic products in the consumption structure of modern societies, extensive research on this subject should be conducted.
\end{abstract}

Key words: organic farming, ecological production, market of organic products, sustainable development, European Union, Europe

\section{Wstęp}

Rolnictwo ekologiczne to produkcja sprzyjająca środowisku naturalnemu i dostarczająca wysokiej jakości artykułów żywnościowych. A zatem produkcja ekologiczna łączy przyjazne środowisku praktyki gospodarowania, wspomaga wysoki stopień różnorodności biologicznej, ochronę zasobów naturalnych, stosować wysokie

${ }^{1}$ mgr inż., Zakład Produkcji i Bezpieczeństwa Żywności PWSZ w Krośnie, ul. Dmochowskiego 12, 38-400 Krosno, e-mail: elabragiel@interia.pl

${ }^{2}$ dr. hab., prof. UR, Katedry Makroekonomii i Stosunków Międzynarodowych UR, ul. M. Ćwiklińskiej 2,

35-601 Rzeszów, e-mail: boguslaw.slusarczyk@gmail.com 
standardy dotyczące dobrostanu zwierząt oraz stosować metody produkcji odpowiadające wymaganiom konsumentów preferujących wyroby wytwarzane przy użyciu substancji naturalnych i naturalnych procesów. Ekologiczna metoda produkcji pełni zatem podwójną funkcję społeczną. Przede wszystkim jest to system wpływający pozytywnie na środowisko naturalne, co też przyczynia się do osiągania szeroko rozumianych korzyści rolnośrodowiskowych. $Z$ drugiej jednak strony, rolnictwo ekologiczne jest odpowiedzią na zmieniającą się strukturę popytu na rynku. Konsumenci skłaniają się ku produktom ekologicznym, chcą je kupować i zazwyczaj płaca za nie wyższą cenę niż za produkty, które nie zostały wytworzone takimi metodami (Rolnictwo..., www.minrol.gov.pl 2017, Rozporząadzenie Rady (WE) nr 834/2007). Jak stwierdza Łuczka-Bakuła (2007) relacje cen żywności ekologicznej do cen żywności konwencjonalnej w Unii Europejskiej są silnie zróżnicowane (osiągają w niektórych krajach poziom ponad 300\%) i zależą m.in. od dojrzałości rynku, relacji popytowo-podażowej i kanałów dystrybucji. Zgodnie z tym podejściem system rolnictwa ekologicznego jest systemem rynkowym Na podstawie tych definicji można powiedzieć, że rolnictwo ekologiczne jest jedyną gałęzią gospodarki narodowej charakteryzującą się pełnym dopasowaniem do rytmu życia przyrody. Ekologiczne środki produkcji zapewniają dalszą produktywność gleby, a także gwarantują bezpieczeństwo zdrowotne wszelkich produktów, zarówno pochodzenia roślinnego, jak i zwierzęcego (Nestorowicz, Pilarczyk, 2010). Spełnia ono oczekiwania konsumentów Unii Europejskiej w zakresie wysokiej jakości żywności, wspierającej środowisko naturalne, dobrostan zwierząt i rozwój obszarów wiejskich (Organic..., 2016).

Produkcja żywności metodami ekologicznymi ma ogromne znaczenie $\mathrm{w}$ tak mocno dziś propagowanej koncepcji zrównoważonego rozwoju. Strategia ta powinna realizować cele społeczne, ekonomiczne i ekologiczne. Łączy ona działania, które mają zaspokoić podstawowe potrzeby społeczeństwa, poprawić jakość życia oraz zapewnić odpowiednią ilość dóbr i usług z działaniami zmierzającymi do poprawy stanu środowiska naturalnego i ochrony jego dóbr (Domagalska, Buczkowska, 2015).

Produkcja ekologiczna to innowacja, postęp i bardzo wysoki poziom specjalistycznej wiedzy. W rolnictwie ekologicznym, aby osiągnąc zadowalające plony, trzeba rozumieć przyrodę, rolnictwo i procesy związane z uprawą każdej rośliny. Rolnictwo ekologiczne to sztuka kierowania tymi procesami i tymi mechanizmami, tak aby uzyskać produkt najwyższej jakości (Rzytki, 2015).

W ujęciu rynkowym produkcja żywności metodami ekologicznymi jest jedną z odpowiedzi na zmieniającą się strukturę popytu na rynku. Po wielkiej fascynacji świata produkcją żywności w warunkach przemysłowych - konsument coraz częściej stwierdza, że tylko żywność powstała w warunkach jak najbardziej zbliżonych do naturalnych spełni jego oczekiwania (Rzytki, 2015). Funkcjonowanie systemu kontroli i certyfikacji w rolnictwie ekologicznym jest podstawowym gwarantem dla konsumenta, że produkty spożywcze znajdujące się na rynku wyprodukowane zostały zgodnie z obowiązującymi przepisami dotyczącymi rolnictwa ekologicznego i są wolne od zanieczyszczeń, takich jak: pozostałości środków ochrony roślin i hormonów, a podczas ich produkcji nie stosowano nawozów sztucznych i organizmów zmodyfikowanych genetycznie (Kontrola..., 2017). Zdaniem Stolze, Zanoli, Meredith (2016) w 2030 roku około 50\% europejskich gruntów rolnych będzie zarządzane zgodnie z zasadami rolnictwa ekologicznego opartego na zdrowiu, ekologii, uczciwości i apatii.

W ciągu ostatnich trzydziestu lat żywność i rolnictwo ekologiczne prężnie się rozwija w całej Europie (Willer, Schaack, Lernoud, Meredith, 2016). W wielu krajach Europy 
niestety nie prowadzi się dokładnych statystyk dotyczących produkcji i sprzedaży produktów ekologicznych, brak jest też badań ogólnokrajowych, czy unijnych dotyczących tak ważnej gałęzi rynku. Korzystając $\mathrm{z}$ dostępnych statystyk krajowych i europejskich należy śledzić rozwój tego systemu produkcji, jej wartość rynkową, asortyment w poszczególnych krajach zwłaszcza UE i odpowiednio kształtować politykę każdego państwa w tym tak ważnym obszarze gospodarki.

\section{Cel i metody badań}

Celem niniejszego opracowania jest analiza wielkości sprzedaży i konsumpcji produktów ekologicznych oraz trendów występujących na tym rynku w poszczególnych krajach Europy a zwłaszcza Unii Europejskiej. Autorzy artykułu zwracają uwagę na zmiany dokonujące się $\mathrm{W}$ strukturze popytu i konsumpcji żywności ekologicznej społeczeństw poszczególnych krajów wskazując na ich determinanty.

Materiał źródłowy analizy stanowiły dane statystyczne ekologicznych organizacji międzynarodowych tj.: Międzynarodowej Federacji Rolnictwa Ekologicznego - IFOAM i Instytutu Badań Rolnictwa Ekologicznego - FIBL oraz krajowej organizacji: Inspekcji Jakości Handlowej Artykułów Rolno-Spożywczych - IJHARS z lat 2000-2015, a także zagraniczna i krajowa literatura przedmiotu. W toku badan wykorzystano metody statystyki opisowej oraz metody prezentacji tabelarycznej i graficznej.

\section{Wyniki badań i dyskusja}

Światowy rynek produktów ekologicznych w 2014 roku osiągną wartość 62,6 miliarda euro, z czego na Europę przypadało prawie $42 \%$ (tab. 1). W Unii Europejskiej najwyższa jest konsumpcja na jedną osobę, jak też udział w całkowitej powierzchni. Powierzchnia gospodarstw ekologicznych w Europie stanowi 2,4\% udziału w światowej powierzchni użytków ekologicznych. Spośród wszystkich producentów ekologicznych na świecie, w Europie prowadzi działalność 15\%.

Tabela 1. Charakterystyka produkcji i sprzedaży ekologicznej w 2014 roku

Table 1. Characteristics of organic production and sales in 2014

\begin{tabular}{l|rcrcc}
\hline Kraj/grupa & $\begin{array}{c}\text { Sprzedaż } \\
\text { detaliczna } \\
\text { (mld euro) }\end{array}$ & $\begin{array}{c}\text { Konsumpcja na } \\
\text { 1 osobę (euro) }\end{array}$ & Producenci & $\begin{array}{c}\text { Powierzchnia } \\
\text { gospodarstw } \\
\text { (mln ha) }\end{array}$ & $\begin{array}{c}\text { Udziałw } \\
\text { całkowitej } \\
\text { powierzchni } \\
\text { (\%) }\end{array}$ \\
\hline EU-28 & 24,0 & 47,4 & 257525 & 10,3 & 5,7 \\
Europa & 26,2 & 35,5 & 339824 & 11,6 & 2,4 \\
Świat & 62,6 & 8,3 & 2260361 & 43,7 & 1,0 \\
EU-15 & 23,5 & 58,0 & 194979 & 7,8 & 6,1 \\
EU-13 & 0,5 & 4,0 & 62546 & 2,4 & 4,7 \\
\hline
\end{tabular}

Źródło: opracowanie własne na podstawie Organic in Europe 2016, FIBL 2016. 
Rynek żywnościowych produktów ekologicznych w Europie i samej UE rozwija się dynamicznie od wielu lat. Produkcja ekologiczna i jej wartość w całym rynku produktów spożywczych zyskuje na znaczeniu w każdym roku, zaspokaja ona rosnące potrzeby konsumentów, podnosi dochody rolników m.in. poprzez wyższe ceny produktów i stosowane dopłaty w ramach Wspólnej Polityki Rolnej oraz przyczynia się do realizacji strategii zrównoważonego rozwoju rolnictwa. Według danych IFOAM w latach 2000-2015 wartość sprzedaży produktów ekologicznych na europejskim rynku wzrosła z 7 miliardów euro do 29,8 miliarda euro, a więc nastąpił wzrost aż o prawie $326 \%$ (rys. 1). W samej Unii Europejskiej odnotowano w tym samym czasie wzrost sprzedaży produktów ekologicznych o 20,6 miliarda euro, tj. o 316,9\%. Trend wielkości sprzedaży produktów ekologicznych na przestrzeni piętnastu lat jest wzrostowy, tak w całej Europie jak i Unii Europejskiej. Roczny przyrost wielkości sprzedaży produktów ekologicznych w Europie w badanym okresie wyniósł przeciętnie 1,4 miliarda euro a w Unii Europejskiej 1,3 miliarda euro.



Rys. 1. Sprzedaż produktów ekologicznych w Europie i Unii Europejskiej w latach 2000-2015 (mld euro) Fig. 1. Sales of organic products in Europe and the European Union in the years 2000-2015 (billion euros) Źródło: opracowanie własne na podstawie Europe statistics 2017.

Porównując wielkość sprzedaży produktów ekologicznych w całej Europie i samej Unii Europejskiej możemy zauważyć oprócz wzrostowej tendencji w obu przypadkach, wyższe tempo wzrostu wielkości sprzedaży w Europie. W latach 2001-2007 różnica między Europą a grupa krajów Unii Europejskiej w wielkości sprzedaży utrzymywała się średnio na poziomie 0,75 miliarda euro. Od roku 2008, ta różnica wyniosła 2 miliardy euro, średnio utrzymywała się do 2015 roku na poziomie 1,9 miliarda euro. Największą różnicę zanotowano w ostatnim badanym roku - 2015, w którym wielkość sprzedaży była wyższa o 2,7 miliarda euro w całej Europie w porównaniu do krajów Unii Europejskiej.

Sytuację na rynku produktów ekologicznych dotyczącą wielkości sprzedaży i zwiększającej się dysproporcji w całej Europie, jak i samej Unii Europejskiej dokładniej obrazuje wielkość sprzedaży w poszczególnych krajach. Najwyższą sprzedaż w latach 2014, 2015 osiągnęły Niemcy (rys. 2). W 2015 roku w Niemczech sprzedaż wynosiła 8,6 mld euro, tj. wyższą o ponad 3 mld euro od Francji, która jest na drugim miejscu, 
i o ponad 6 mld euro więcej od Wielkiej Brytanii. Czwarte miejsce pod względem wielkości sprzedaży zajmują Włochy (2,3 mld euro), a piąte Szwajcaria z wynikiem 2,1 mld euro. Wśród 15 państw o największej sprzedaży produktów ekologicznych na miejscu 14 znajduje się Polska ze sprzedażą na poziomie 167 mln euro w 2015 roku. Wolumen sprzedaży produktów ekologicznych 2015 roku osiągnięty przez wskazaną „15-kę europejską" wyniósł ponad 29,1 miliarda euro, był o 14\% wyższy niż rok wcześniej.

Najwyższy poziom sprzedaży produktów "eko" oraz "bio" notuje się w krajach najbogatszych, ponieważ czynnikami od których zależy poziom konsumpcji są dochody gospodarstwa domowego, jak i ceny produktów substytucyjnych (Brodzińska, 2014; Ligenzowska, 2014). W Niemczech, gdzie popyt na żywność ekologiczną jest największy, regionalna żywność ekologiczna promowana jest poprzez nadanie specjalnego certyfikatu „fair \& regional”. Celem tych działań jest to, by za pomocą charakterystycznej cechy wyróżnić produkty, które nie tylko są ekologiczne, ale również związane z generowaniem miejsc pracy w regionie (Brodzińska, 2014).

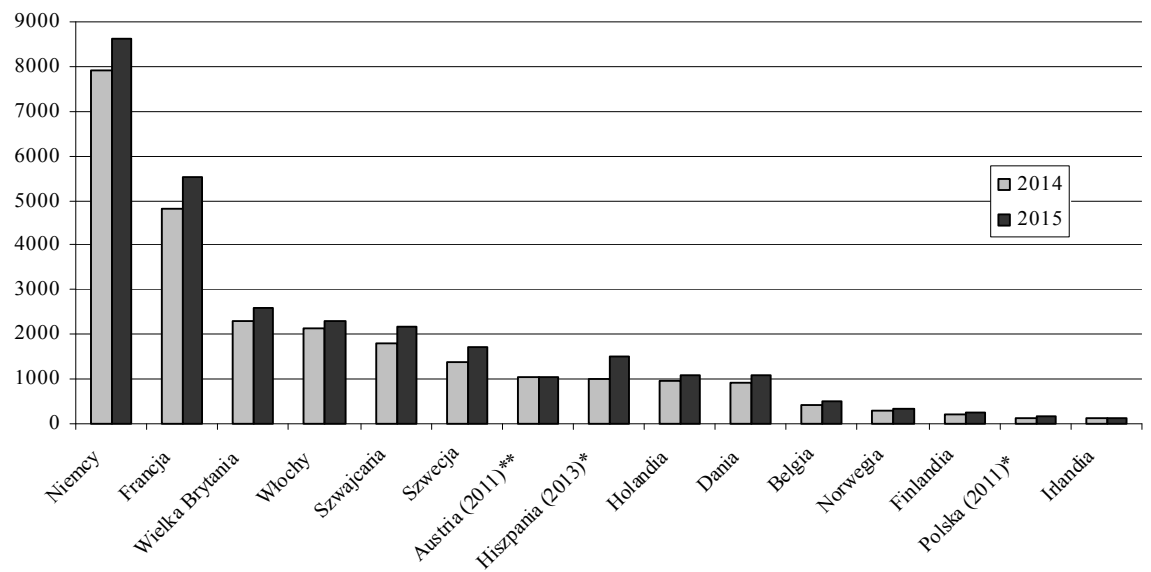

* dane ujęte w roku 2014, ** z uwagi na brak danych ujęte w roku 2014 i 2015

Rys. 2. Państwa w Europie o największej sprzedaży produktów ekologicznych (powyżej 100 milionów euro) w 2014 i 2015 roku (mln euro)

Fig. 2. European countries with the highest sales of organic products (over 100 million euros) in 2014 i 2015 (mln euros)

Źródło: opracowanie własne na podstawie Organic in Europe 2016, Europe statistics 2017.

Największa dynamika sprzedaży produktów ekologicznych w $2015 \mathrm{w}$ stosunku do 2014 roku wystąiła w takich krajach jak: Irlandia - 34,6\%, Norwegia - 26,7\%, Szwecja $23,1 \%$ i Szwajcaria - 19,7\%, a więc krajach o rozwijającym się rynku produktów ekologicznych (rys. 3). Niższe, ale znaczące tempo wzrostu sprzedaży odnotowano także w krajach, w których mamy do czynienia z tzw. rynkiem dojrzałym, tj. Danią, Belgią, Francją i Wielką Brytanią.

Jak wskazują Runowski (2009) i Brodzińska (2010) w krajach UE niezwykle ważnym determinantem rozwoju rolnictwa ekologicznego jest poziom wsparcia finansowego tego 
systemu produkcji. W krajach o niskim i umiarkowanym poziomie wsparcia, zainteresowanie rolników przestawianiem gospodarstw na system rolnictwa ekologicznego maleje.

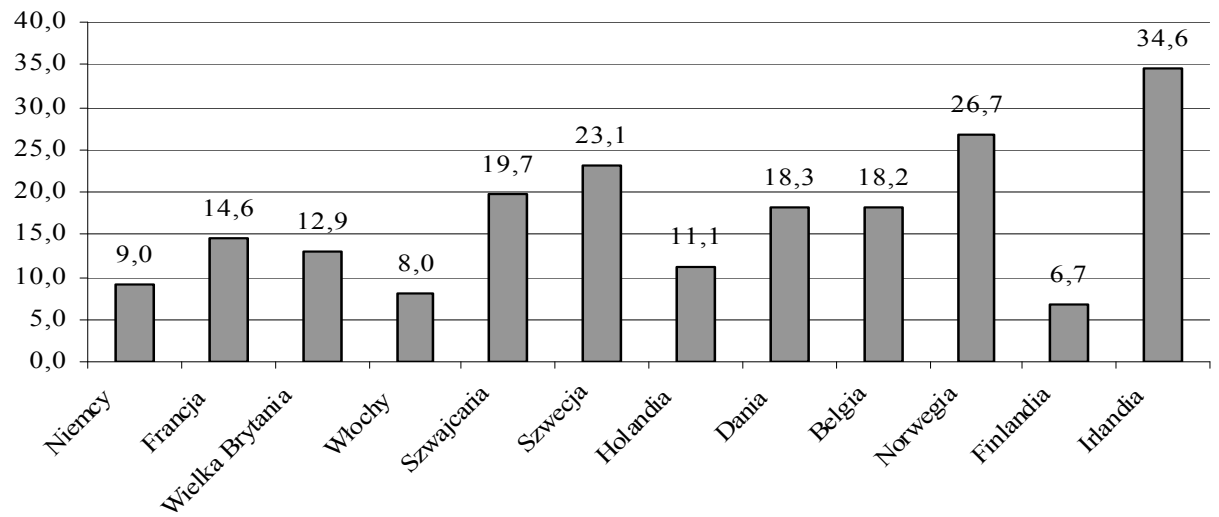

Rys. 3. Dynamika wielkości sprzedaży produktów ekologicznych w Europie w krajach o największej sprzedaży w 2015 w stosunku do 2014 roku

Fig. 3. The dynamics of sales volume of organic products in Europe in the countries with the highest sales in 2015 compared to 2014 years

Źródło: opracowanie własne na podstawie Organic in Europe 2016, Europe statistics 2017.

Analizując rynek produktów ekologicznych i jego rozwój w poszczególnych krajach europejskich, trzeba także zwrócić uwagę na udział wielkości sprzedaży produktów ekologicznych w całości sprzedaży produktów spożywczych. Państwem o najwyższym udziale w sprzedaży produktów ekologicznych w 2014 roku jest Dania - 7,6\%, która pod względem wielkości sprzedaży zajmuje dopiero 10 miejsce, następnie Szwajcaria z udziałem 7,1\% (5 miejsce pod względem sprzedaży) i Austria 6,5\% (rys. 4).

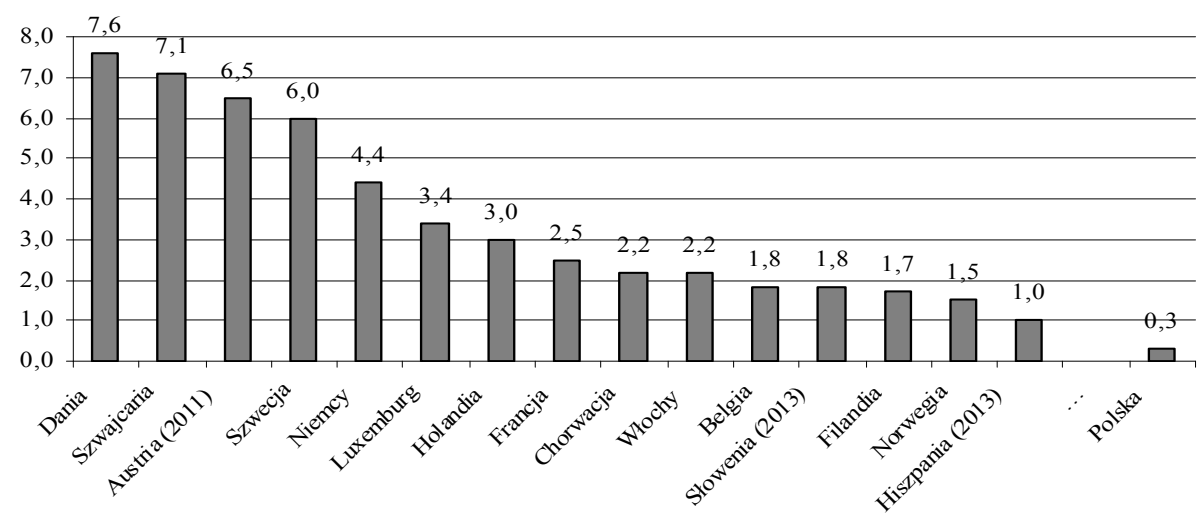

Rys. 4. Państwa w Europie o największym udziale wielkości sprzedaży detalicznej produktów ekologicznych w 2014 roku

Fig. 4. European countries with the highest share of sales retail of organic products in 2014

Źródło: opracowanie własne na podstawie Organic in Europe 2016, Europe statistics 2017, Strużyna S. 2015. 
Niemcy mając największą wartość sprzedaży na rynku produktów ekologicznych, posiadają 4,4\% udziału produktów ekologicznych w sprzedaży produktów spożywczych. W Polsce udział ten w porównaniu do innych krajów europejskich kształtuje się na niskim poziomie $0,3 \%$. Czternaste miejsce Polski w wielkości sprzedaży produktów ekologicznych i jednocześnie niski udział w sprzedaży krajowej wskazuje, że jesteśmy krajem, którego produkcja w dużym stopniu, ze względu na niski popyt krajowy, jest przeznaczana na eksport.

Zasadniczą determinantą, tendencji wzrostowej wielkości sprzedaży produktów ekologicznych w poszczególnych krajach jest wzrost popytu na te produkty, a więc wzrost wartości konsumpcji na 1 mieszkańca (rys. 5).

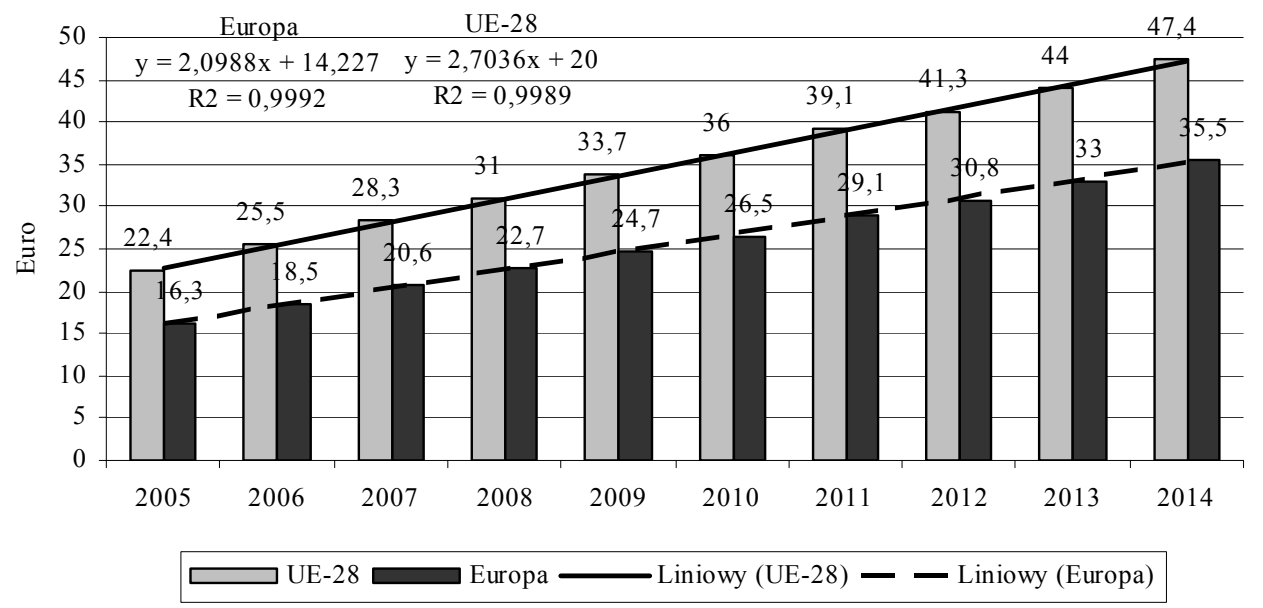

Rys. 5. Wartość konsumpcji produktów ekologicznych na jednego mieszkańca w Europie (w euro)

Fig. 5. The volume of consumption for organic products per capita in Europe (in euros)

Źródło: opracowanie własne na podstawie Organic in Europe 2016, Europe statistics 2017.

Na przestrzeni lat 2005-2014 wartość konsumpcji z roku na rok wzrastała średnio o 2,7 euro w krajach Unii Europejskiej i o 2,1 euro w całej Europie na jednego mieszkańca. Przeciętne wydatki na produkty ekologiczne jednego mieszkańca w Unii Europejskiej wzrosły z 22,4 euro w 2005 do aż 47,4 euro w 2014, tj. aż o 111\%. W Europie, w tym samym okresie wydatki jednego mieszkańca na żywność ekologiczną wzrosły z 16,3 euro do 35,5 euro, co daje wzrost o $118 \%$. Różnica w wydatkach na żywność ekologiczną na jednego mieszkańca Unii Europejskiej a wszystkich Europejczyków powiększa się z każdym rokiem. W 2005 roku wynosiła ona 6,1 euro, a w 2014 już 11,9 euro. Jeśli porównamy wielkość sprzedaży w latach 2005-2014 (rys. 1) i wysokość wydatków na konsumpcję na jednego mieszkańca (rys. 5), można zauważyć, że wielkość sprzedaży w całej Europie była wyższa niż w samej Unii Europejskiej, ale sytuacja jest odwrotna jeśli chodzi o wydatki na jednego mieszkańca - w UE są wyższe niż w Europie.

Średnie unijne wydatki na produkty ekologiczne na jednego mieszkańca w 2014 roku wyniosły 47,4 euro (rys. 6). Rekordzistami pod względem wydatków na produkty 
ekologiczne na jednego mieszkańca są Szwajcaria - 221,5 euro, Luxemburg - 163,7 euro, Dania - 162,1 euro, czy Szwecja 145,4 euro.

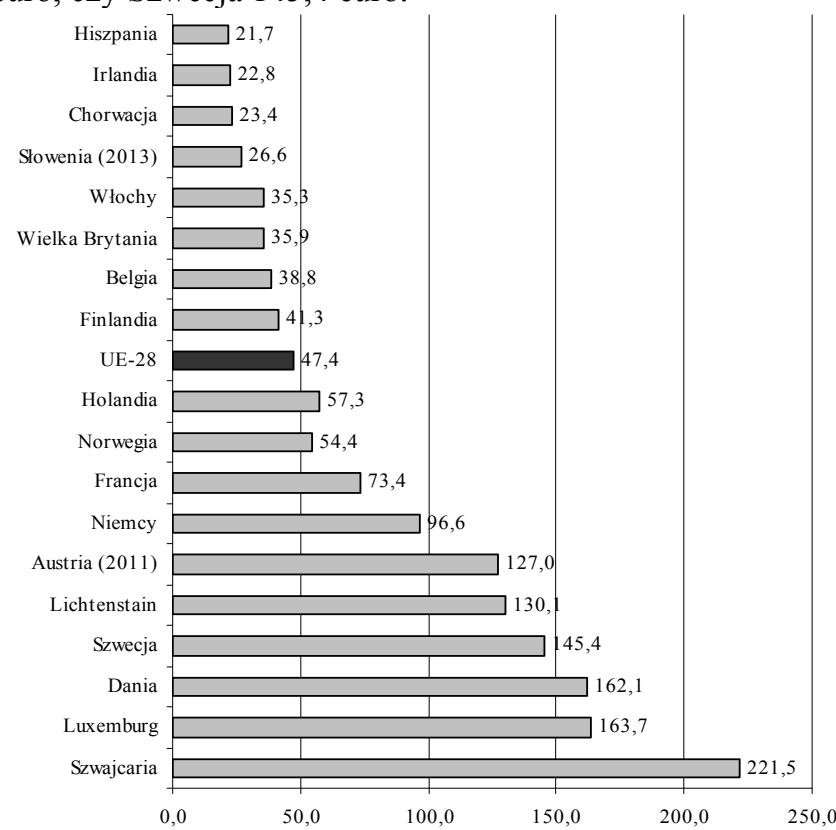

Rys. 6. Wartość sprzedaży produktów ekologicznych w Europie na jednego mieszkańca wg poszczególnych krajów w 2014 roku (euro/mieszkańca)

Fig. 6. Sales value consumption of organic products in Europe per capita in particular countries in 2014

Źródło: opracowanie własne na podstawie Organic in Europe 2016, Europe statistics 2017.

W 2015 roku kraje o najwyższych wydatkach odnotowały kolejne wysokie wartości w wydatkach na żywność ekologiczną na jednego mieszkańca (tab. 2).

Tabela 2. Spożycie produktów ekologicznych powyżej 20 Euro w Europie na jednego mieszkańca wg poszczególnych krajów

Table 2. Consumption of organic products in Europe over 20 EUR per capita in particular countries

\begin{tabular}{l|ccc}
\hline \multicolumn{1}{c|}{ Kraj } & 2014 & 2015 & Dynamika 2015/2014 \\
\hline Szwajcaria & 221,5 & 262,2 & 118,4 \\
Luxemburg & 163,7 & 170,0 & 103,8 \\
Dania & 162,1 & 190,7 & 117,6 \\
Szwecja & 145,4 & 177,1 & 121,8 \\
Lichtenstein & 130,1 & 142,4 & 109,5 \\
Niemcy & 96,6 & 105,9 & 109,6 \\
Francja & 73,4 & 83,3 & 113,5 \\
Norwegia & 54,4 & 68,1 & 125,2 \\
Holandia & 57,3 & 63,4 & 110,6 \\
\hline
\end{tabular}

Źródło: opracowanie własne na podstawie Organic in Europe 2016, Europe statistics 2017. 
W 2015 roku w stosunku do 2014 roku wydatki na produkty ekologiczne na jednego mieszkańca wzrosły w Szwajcarii, mimo i tak wysokiej wartości o 18,4 \% do 262,2 euro. W Dani odnotowano wzrost o $17,6 \%$, i awansowała na drugie miejsce pod względem wydatków na produkty ekologiczne z kwotą 190,7 euro. Na trzecim miejscu znajduje się Szwecja ze wzrostem o $21,8 \%$ i kwotą 177,1 euro. W Polsce wydaje się na produkty ekologiczne około 5 euro na osobę (Strużyna, 2015), tj. około 9,5 razy mniej niż średnio wydaje mieszkaniec Unii Europejskiej i o 52,4 razy mniej niż mieszkaniec Szwajcarii.

\section{Podsumowanie i wnioski}

Rynek produktów ekologicznych posiada swoją specyfikę, która jest uwarunkowana swoistymi zachowaniami i świadomością ekologiczną konsumentów, stopniem rozwoju gospodarczego i majętnością, prowadzoną polityką rolną oraz warunkami naturalnymi panującymi na terenie poszczególnych Państw UE jak i całego świata (Domagalska, Buczkowska, 2015). Rynek produktów ekologicznych dopiero się kształtuje i zachodzą na nim dynamiczne zmiany, a poszczególne kraje walczą o swoje pozycje. Konkurencja w warunkach wolnego handlu jest jednak duża, a wymagania konsumentów wysokie. Ważna jest, nie tylko jakość produktów, ale również stopień ich przetworzenia i dostępność (Nowogródzka, 2012).

Podsumowując wyniki badań sformułowano następujące wnioski końcowe:

1. Rynek produktów ekologicznych dynamicznie się rozwija. Trend wielkości sprzedaży produktów ekologicznych na przestrzeni omawianych piętnastu lat jest wzrostowy, tak w całej Europie, jak i grupie krajów Unii Europejskiej, wyższe tempo wzrostu odnotowuje się w Europie.

2. Najwyższą sprzedaż produktów ekologicznych w latach 2014, 2015 osiągnęły Niemcy, Francja, Wielka Brytania, Włochy i Szwajcaria.

3. Największa dynamika sprzedaży produktów ekologicznych w $2015 \mathrm{w}$ stosunku do 2014 roku wystąpiła w Irlandii, Norwegii, Szwecji i Szwajcarii, a więc krajach o rozwijającym się rynku produktów ekologicznych. Niższe, ale znaczące tempo wzrostu sprzedaży produktów ekologicznych odnotowano także w krajach, z tzw. rynkiem dojrzałym, tj. Dani, Belgi, Francji i Wielkiej Brytanii.

4. Państwami o najwyższym udziale sprzedaży produktów ekologicznych w całości sprzedaży produktów spożywczych w 2014 roku były: Dania, która pod względem wielkości sprzedaży zajmuje dopiero 10 miejsce, następnie Szwajcaria (5 miejsce pod względem sprzedaży) i Austria.

5. Na przestrzeni lat 2005-2014 wartość konsumpcji z roku na rok wzrastała średnio o 2,7 euro w krajach Unii Europejskiej i o 2,1 euro w całej Europie na jednego mieszkańca. Różnica w wydatkach na żywność ekologiczną na jednego mieszkańca Unii Europejskiej a w całej Europie powiększa się z każdym rokiem.

6. Średnie unijne wydatki na produkty ekologiczne na jednego mieszkańca w 2014 roku wyniosły 47,4 euro. Najwięcej na produkty ekologiczne na jednego mieszkańca wydaje się w Szwajcarii, Luxemburgu, Danii i Szwecji. W Polsce wydatki na produkty ekologiczne były 9,5 razy mniejsze niż średnio w Unii Europejskiej i o 52,4 razy mniej niż mieszkaniec Szwajcarii. 
Biorąc po uwagę rosnący udział produktów ekologicznych w strukturze spożycia współczesnych społeczeństw należy prowadzić szeroko zakrojone badania na temat możliwości ich produkcji, rozszerzenia asortymentu, przetwórstwa, dostosowania dystrybucji do oczekiwań konsumentów i przedsięwzięć promocyjnych, a także podjąć działania edukacyjne kształtujące świadomość społeczną w zakresie produkcji, jakości i kontroli produktów ekologicznych oraz ich wpływu na zdrowie i środowisko naturalne.

Światowy i europejski rynek żywności ekologicznej stoi przed wielką szansą rozwoju, a wraz ze wzrostem świadomości ekologicznej i poziomu zamożności społeczeństw, zwiększa się zainteresowanie tego typu produktami (Domagalska, Buczkowska, 2015).

\section{Literatura}

Brodzińska, K. (2010). Rozwój rolnictwa ekologicznego w Polsce na tle uwarunkowań przyrodniczych i systemu wsparcia finansowego. Zeszyty Naukowe SGGW Problemy Rolnictwa Światowego, 10(2), 12-21.

Brodzińska, K. (2014). Rolnictwo ekologiczne - tendencje i kierunki zmian. Zeszyty Naukowe SGGW Problemy Rolnictwa Światowego, 14(3), 27-36.

Domagalska, J. Buczkowska, M. (2015). Rolnictwo ekologiczne-szanse i perspektywy rozwoju. Problemy Higieny i Epidemiolgii, 96(2), 370-376.

Europe statistics W: Willer, H., Lernoud, J. (red.) (2017): The World of Organic Agriculture. Statistics and Emerging Trends. FiBL \& IFOAM - Organicrs International (2017): Frick and Bonn, 206-243. Pobrane 10 kwietnia $2017 \mathrm{z}$ : https://core.ac.uk/download/pdf/77086835.pdf

Graczyk, A. Mazurek-Łopacińska K. (red). (2009). Badanie rozwoju rynków produktów rolnictwa ekologicznego i żywności ekologicznej w Polsce. Wyd. UE we Wrocławiu, Wrocław.

Kontrola i certyfikacja Pobrane 14 kwietnia 2017 z: http://www.minrol.gov.pl/Jakosc-zywnosci/Rolnictwoekologiczne/Kontrola-i-certyfikacja

Ligenzowska, J. (2014). Rolnictwo ekologiczne na świecie. Zeszyty Naukowe SGGW Problemy Rolnictwa Światowego, 14(3), 150-157.

Łuczka- Bakuła W. (2007). Rynek żywności ekologicznej. Wyd. PWE, Warszawa.

Stolze, M., Zanoli, R., Meredith, S. (2016). Organic in Europe: expanding beyond a niche. W: Organic in Europe. Prospects and developments 2016. Red. H. Willer, S. Meredith. IFOAM UE Group. Pobrane 10 kwietnia $2017 \mathrm{z}$ : http://www.ifoam-eu.org/sites/default/files/ifoameu_organic_in_europe_2016.pdf.

Nestorowicz, R., Pilarczyk, B. (2010). Marketing ekologicznych produktów żywnościowych. W: Rolnictwo ekologiczne jako obszar działań marketingowych. Nestorowicz R, Pilarczyk B (red). Oficyna, Warszawa, 38-70.

Nowogródzka, T. (2012) Stan i perspektywy rozwoju rolnictwa ekologicznego w Polsce. Zeszyty Naukowe SGGW Problemy Rolnictwa Światowego, 12(2), 54-64.

Organic in Europe. Prospects and developments 2016. IFOAM UE Group, 12 Pobrane 10 kwietnia 2017 z: http://www.ifoam-eu.org/sites/default/files/ifoameu_organic_in_europe_2016.pdf.

Rolnictwo ekologiczne Pobrane 10 kwietnia 2017 z: http://www.minrol.gov.pl/Jakosc-zywnosci/Rolnictwoekologiczne.

ROZPORZĄDZENIE RADY (WE) nr 834/2007 z dnia 28 czerwca 2007 r. w sprawie produkcji ekologicznej i znakowania produktów ekologicznych i uchylające rozporządzenie (EWG) nr 2092/91 Dziennik Urzędowy Unii Europejskiej L 189/1 Dz.Urz. L 189 z 20.07.2007 r., 1).

Runowski, H. (2009). Rolnictwo ekologiczne - rozwój czy regres? Roczniki Nauk Rolniczych, Seria G, 96(4), $182-193$.

Rzytki, M. (2015). Rolnictwo ekologiczne. Biuletyn informacyjny. ARR, 4, 22-25.

Strużyna, S. (2015). Dystrybucja produktów ekologicznych w Polsce. Biuletyn informacyjny ARR, 4, 32-34.

Willer, H., Schaack, D., Lernoud, J., Meredith, S. (2016). Growth trends in European Organic Food and Farming Organic Farming and Market Development in Europe W: Organic in Europe. Prospects and developments 2016. Red. H. Willer, S. Meredith. IFOAM UE Group. Pobrane 10 kwietnia 2017 z: http://www.ifoameu.org/sites/default/files/ifoameu_organic_in_europe_2016.pdf. 